\title{
Effect of Soil Treatments and Amendments on the Nematode Community under Miscanthus Growing in a Lead Contaminated Military Site
}

\author{
Zafer Alasmary ${ }^{1}$, Tim Todd ${ }^{2}$, Ganga M. Hettiarachchi ${ }^{1}{ }^{10}$, Tatyana Stefanovska ${ }^{3}$, \\ Valentina Pidlisnyuk ${ }^{4}$, Kraig Roozeboom ${ }^{1}{ }^{\circledR}$, Larry Erickson ${ }^{5}{ }^{(0}$, Lawrence Davis ${ }^{6}$ \\ and Olexander Zhukov ${ }^{7 \text {,* }}$ \\ 1 Department of Agronomy, Kansas State University, Manhattan, KS 66506, USA; zalasmary@ksu.edu (Z.A.); \\ ganga@ksu.edu (G.M.H.); kraig@ksu.edu (K.R.) \\ 2 Department of Plant Pathology, Kansas State University, Manhattan, KS 66506, USA; nema@ksu.edu \\ 3 Department of Entomology, National University of Life and Environmental Sciences, 03041 Kyiv, Ukraine; \\ tstefanovska@nubip.edu.ua \\ 4 Department of the Environmental Chemistry and Technology, Jan Evangelista Purkyne University, \\ 40096 Usti nad Labem, Czech Republic; valentyna.pidlisniuk@ujep.cz \\ 5 Tim Taylor Department of Chemical Engineering, Kansas State University, Manhattan, KS 66506, USA; \\ lerick@ksu.edu \\ 6 Department of Biochemistry and Molecular Biophysics, Kansas State University, Manhattan, KS 66506, USA; \\ ldavis@ksu.edu \\ 7 Department of Botany and Horticulture, Bogdan Khmelnitsky Melitopol State Pedagogical University, \\ 72318 Melitopol, Ukraine \\ * Correspondence: zhukov_dnipro@ukr.net
}

Received: 19 September 2020; Accepted: 3 November 2020; Published: 6 November 2020

\begin{abstract}
Applying phytotechnologies with energy crops on lands contaminated with trace elements provides cellulosic biomass and improves soil health. The process can be reflected in changes in the soil nematode community structure. This study assessed the nematode community composition of soil with Miscanthus grown with different agronomic practices. The research was conducted at Fort Riley, Kansas, USA, in soil with aged contamination by Pb at 1000 to $1500 \mathrm{mg} / \mathrm{kg}$. The experimental design was a randomized complete block composed of four replications of five treatments: Control-undisturbed mixed plant cover and four conditions of Miscanthus growth, which consisted of No-till, Till (immediately before planting), Till $+\mathrm{P}$, and Till + biosolids. Analysis of abundance, diversity, and community functional status indicators showed differential sensitivity of nematode taxa to agronomic treatments. Significant transformations in the nematode trophic group structure occurred under Miscanthus cultivation compared with the undisturbed mixed plant cover. Shannon and Pielou index response to agronomic treatments illustrated decreasing nematode community diversity with all Miscanthus agronomic conditions. However, agronomic practices led to increasing nematode community maturity, but those effects varied between spring and fall seasons. Increasing herbivores and omnivore-predators were the primary drivers of the observed changes in the nematode community due to planting Miscanthus. The nematode ecological structure indicators suggested that growth in Pb-contaminated land using different agronomical practices likely affects essential soil processes. More study is needed to define the effects of pre-plant tillage and amendments to soil nematode communities and Miscanthus yield over multiple growing seasons of this perennial crop.
\end{abstract}

Keywords: nematode communities; maturity index; diversity; mixed vegetation; phytotechnology; agronomic practices; biosolids; trophic groups; soil pollution 


\section{Introduction}

The sterile, triploid perennial grass, Miscanthus (Greef et Deu), is considered one of the most promising second-generation biofuel crops. Miscanthus species have a C-4 photosynthetic pathway and an excellent environmental profile with the potential to increase soil carbon, tilth, and biodiversity and to reduce nutrient run-off and leaching [1,2]. Recent laboratory and field experiments demonstrated $[3,4]$ that Miscanthus produces a high yield on marginal and contaminated lands and can be used for phytostabilisation of soils contaminated by trace elements of different anthropogenic origins, including marginal [4,5], post-mining [6-8], and military [9]. The approach is useful when contaminated sites cover relatively large areas and are only slightly or moderately contaminated. Combining phytoremediation with biomass production facilitates restoring the land while simultaneously meeting the demand for biomass as an alternative energy source and raw material for bioproducts. In 2016, a long-term study was initiated to explore the potential of sustainable Miscanthus production in aged soil contaminated primarily by $\mathrm{Pb}$ on a former tallgrass prairie zone at Fort Riley, KS [10]. The long-term study was designed to evaluate how different establishment methods and soil amendments affect plant productivity, $\mathrm{Pb}$ accumulation by biomass, and soil $\mathrm{Pb}$ stability, including chemical speciation. It also provided the opportunity to investigate how crop management practices might impact underground biodiversity, particularly nematodes. Different soil treatments and amendments are commonly applied to increase Miscanthus productivity on marginal/polluted land [1], which may impact nematode populations in different ways.

Nematodes are ubiquitous and very abundant in the soil environment, representing a vital component of the soil micro-fauna at most trophic levels in the soil food-web. The nematode community assemblage and trophic structure respond rapidly to fundamental ecological processes of ecosystems: biogeochemical/nutrient cycling, especially nitrogen and phosphorous [11], energy flow, and succession [12-15]. Nematodes are very sensitive and responsive to environmental changes because of the broad ecological range of this taxonomic group presented in terms of the colonizer-persister (c-p) scale of life strategy [16]. This characteristic makes nematodes reliable biological indicators of the soil food dynamics in agricultural and natural ecosystems [17-23]. Analysis of the nematode community (assemblage and feeding groups) over time is an effective way to assess the impact of land use and management practices on soil quality and functioning [24,25].

Several mechanisms regulate the nematode community response to fertilizers, soil amendments, tillage, crop management, and pollution. Shifts in feeding sources induce shifts in the proportions of the related nematode feeding types because they rely on specific resources for growth and reproduction. Application of organic amendments, such as green manure, cattle manure, composts, and slurries, have been documented to suppress the plant-parasitic nematodes and, in many cases, increased the population of free-living nematodes [26-28]. Some researchers found that bacterivores tended to increase generally with the application of organic compost, manure, and cattle waste slurry [29], but in other cases, an increase was observed in plant-parasitic nematodes [30].

Research has shown that biosolids, as an input of organic C, can increase soil biodiversity and improve soil health [31-33]. In the U.S., biosolids are defined as organic residuals obtained after wastewater treatment (primarily residential) that meet the U.S. Environmental Protection Agency pollutant and pathogen requirements for land application and surface disposal. Organic residue from wastewater treatment plants with high levels of metals is generally called sludge. Careful analysis and extreme caution must be used before classifying organic residue as biosolids. The material used in this experiment was obtained from a wastewater treatment plant in Topeka, the capital city of KS, and was certified as Class B biosolids means that they have undergone a Process to Significantly Reduce Pathogens as defined by the United States Environmental Protection Agency. However, because biosolids may contain greater concentrations of non-regulated trace elements or trace organic pollutants of emerging concerns (such as perfluorooctanoic acid, PFOA) than receiving soil, biosolids also may have regressive effects on soil biodiversity and soil health. 
Most available information indicates that soil amendments reduce the plant-parasitic nematode population. Different commercial products, including composted sludge, stabilized biosolids, or coal combustion fly ash, demonstrated a great potential to manage populations of root-knot [34] and cyst nematodes [35,36]. A few studies on the effect of biosolids on nematode communities had some disparity in results. Nematode abundance and diversity were significantly affected by five different biosolids treatments in five soil types [37]. The most evident response to biosolids application was for bacterivores, with a negative correlation between the dose of biosolids and nematode communities. Most of the studies concerning the effects of chemical fertilizers on nematode community composition were focused on nitrogen fertilizers and indicated that inorganic nitrogen reduced nematode diversity in perennial and annual crops [38,39]. Data documenting the effect of phosphorous fertilizers on nematode abundance and diversity are limited. Sarathchandra et al. [38] found insignificant increases in bacterivores, fungivores, and omnivores in response to phosphorus fertilizers but did not detect changes in the Maturity index (MI). Todd [40] observed minor effects of phosphorous fertilization on nematode community structure and diversity. Findings were inconsistent in several other studies of the impact of phosphorous fertilizers on plant-parasitic nematodes. Rovira and Simon [41] reported increases of cyst nematode abundance, whereas Coyne et al. [42] found the opposite trend. Only a few investigations were undertaken on the impact of fertilizers on nematode community composition with Miscanthus grown on agricultural land. Emery et al. [43] observed that nitrogen fertilizers negatively affected nematode diversity in soil under actively growing Miscanthus.

Soil disturbance has been demonstrated to induce shifts in nematode reproduction types (cp-classes) due to the difference between cp-classes in the time needed for population recovery. Among agronomic practices affecting the nematode community, the roles of tillage and organic/synthetic amendments have been studied extensively. However, the results have been inconclusive. Previous investigations have shown that tillage and soil amendments variously affected nematode diversity based on trophic type/life-history strategies and taxa. Greater nematode diversity and relative abundance of fungivores, omnivores, and predators were found in soil from no-till fields [44].

Compared with reduced till and no-till systems, conventional tillage reduced the number of protozoa, bacterivores, and omnivore-carnivores [39,45]. This result can be explained by a shift from a bacteria-based food web to a fungal one following soil disturbance [46]. On the contrary, de Geode et al. [47], Darby et al. [48], Zhao and Neher [49] found that tillage practices along with other soil disturbance and application of mineral fertilizers increased fast-growing bacterivore nematodes. The application of soil amendments likely promotes the shift to bacterivores. Wang et al. [50] and Okada et al. [51] showed greater nematode abundance with increased fungivore, bacterivore, and omnivore populations in the soil of tilled plots with the application of synthetic and organic fertilizers compared to tilled plots without amendments. Lenz and Eisenbeis [52] detected that ecological diversity indices: MI and Plant-Parasitic Index (PPI) are suitable indicators of tillage impact on the nematode community. The Nematode Trophic Diversity (TD) did not respond to tillage disturbance; however, the MI was suitable for indicating immediate tillage effects on the nematode community.

Long-term pollution induced shifts in phylogenetic groups of nematodes because different genetic pre-adaptations exist in those groups. Because nematodes occupy vital positions as primary and intermediate consumers in soil, their response to heavy metals in the soil by changes in their community structure and function has been well documented in previous publications $[53,54]$. The trophic groups responded differently depending on the hazard, the origin of pollution, dose of exposure, distance to the source of pollution, and time passed since heavy metals appeared. Reproduction types and phylogenetic groups are not uniformly distributed across feeding types, therefore secondary effects on feeding types can emerge from disturbance and pollution.

Bacteriovores have shown tolerance to metals [55]. Nematodes responded rapidly to short-term exposure. However, the effect could be long-lasting [56], as was recorded for several historically polluted sites. The nematode assemblages representing c-groups can partly recover in a few years [57]. Commonly, pollution-induced tolerance in nematodes involves selecting tolerant strains within the 
population [58]. The adverse effect of heavy metals on the nematode community was not observed when the soil had been polluted many years previously or over a long period of time $[58,59]$. In one instance, the nematode community had adapted to mining pollution when the exposure had lasted for many hundreds of years [59]. A study conducted after two decades on a former shooting range [59] found that soil pollution by $\mathrm{Pb}$ did not affect soil-dwelling nematodes and microarthropods. The most likely mechanisms responsible for the tolerance of nematodes are avoiding the most contaminated microsites and selection for resistance [60]. In our study, the research site was exposed to $\mathrm{Pb}$ over a several decades, and almost 50 years had passed since the shooting range was in use. Thus, we assumed that nematode fauna might have developed $\mathrm{Pb}$-tolerant populations. Therefore, we did not consider the potential of $\mathrm{Pb}$-contamination to alter nematode communities.

The increasing potential for Miscanthus biomass production in soils contaminated by trace elements may require soil amendments and tillage practices to facilitate Miscanthus establishment and maximize its productivity. However, the soil nematode community's response to the application of agronomic practices during planting of Miscanthus has not yet been studied by nematode faunal analysis. The purpose of this research was to examine the following:

1. Effect on the soil nematode community composition of converting soil from mixed plant cover presented by Medicago sativa L., Bromus tectorum L., Panicum virgatum L., to the production of monoculture represented by Miscanthus.

2. Effect on the soil nematode abundance, diversity, trophic structure, and maturity of tillage and two phosphorous amendments (organic and inorganic) to establish Miscanthus on $\mathrm{Pb}$ contaminated aged soil.

\section{Materials and Methods}

\subsection{Experimental Design}

The research was conducted at Fort Riley (Ft. Riley), US Army, in lead-contaminated soil in the Flint Hills of Northeastern Kansas, USA $\left(96^{\circ} 44^{\prime} 57^{\prime \prime}\right.$ W $\left.39^{\circ} 06^{\prime} 06^{\prime \prime} \mathrm{N}\right)$. The setting was a skeet shooting range, and small lead shot beads ( $50 \mathrm{mg}, 2 \mathrm{~mm}$ diameter apiece) were deposited over time. Each fired shot dispersed over $30 \mathrm{~g}$ of $\mathrm{Pb}$ (585 pellets). The site age is uncertain, owever, skeet shooting was invented in the 1920s and used by the army during WW II to train aircraft personnel, so the site was likely active for several decades. The range at Ft. Riley was abandoned before 1995, and a new one was constructed elsewhere. The lead pellets on the surface were removed. In the early 2000s, the site was subjected to an environmental clean-up when it was plowed and planted to alfalfa. The alfalfa had been mown regularly before the Miscanthus plantation establishment, but other grass and forbe species had invaded by the time the study was initiated. For several years before the experiment, the area was used for training in the operation of all-terrain vehicles. The site was selected for a project within the NATO SPS MYP G4687 "New phytotechnology for military site cleaning", 2016-2021 because of it's history of $\mathrm{Pb}$ contamination. This project's primary goal is to develop the Miscanthus phytotechnology with biomass production on post-military land. At the site in Ft. Riley, different agronomic practices were evaluated to determine the effect of different establishment methods and soil amendments (Table 1) on soil and lead content and stability.

The experimental design was a randomized complete block with four replications. Each plot was $1.83 \times 1.83 \mathrm{~m}$ and had 16 Miscanthus propagules in four rows at $0.46 \mathrm{~m}$ spacing, with alleyways between plots of $0.46 \mathrm{~m}$. All propagules survived, produced a closed canopy, and produced harvestable biomass in the first season. Full details are presented in Almasary 2020 [10]. The use of phosphorus to reduce lead bioavailability was proposed as an effective in situ stabilization option for lead-contaminated soils. Also, to minimize absorption of lead by plants maintaining soil $\mathrm{pH}$ levels above 6.5 to 7.0 was preferred. Therefore, based on soil characteristics, two sources of phosphorus were used as soil treatments/amendments. Those were triple superphosphate (TSP, inorganic phosphorus fertilizer applied at 5:3 Pb: P molar ratio) and class B biosolids (organic source 
of phosphorus applied at $45 \mathrm{mg} / \mathrm{ha}$ ). The experiment started in 2016. The herbicide treatment was on 7 April 2016. The incorporation of amendments was done on the day before planting, 6 May 2016. At the end of each growing season, the biomass yield was estimated along with $\mathrm{Pb}^{\prime} \mathrm{s}$ concentration in biomass and soil. The $\mathrm{Pb}$ concentrations in soil were determined by soil digestions using USEPA method SW846-3051A [61]. The Pb concentrations in the soil digestates were then analyzed with an inductively coupled plasma-optical emission spectrophotometer (ICP-OES, Varian 720-series ICP-OES, Walnut creek, CA, USA).

Table 1. Agronomic practices imposed for 2016 planting of long term Miscanthus planting on a Pb contaminated site at Ft. Riley, Kansas [10].

\begin{tabular}{|c|c|c|c|}
\hline$\#$ & Vegetation & Treatment & Descriptions of Preparation \\
\hline 1 & Existing & Control & Existing vegetation, cut to $2 \mathrm{~cm}$ from soil surface \\
\hline 2 & Miscanthus & No-till & $\begin{array}{l}\text { Vegetation terminated with glyphosate herbicide, and } \\
\text { Miscanthus planted directly into the soil two weeks later }\end{array}$ \\
\hline 3 & Miscanthus & Till & $\begin{array}{l}\text { Vegetation terminated with glyphosate herbicide two } \\
\text { weeks before planting and tilled to } 7 \text { to } 10 \mathrm{~cm} \text { deep } \\
\text { immediately before planting, no amendments }\end{array}$ \\
\hline 4 & Miscanthus & $\begin{array}{l}\text { Till + P (Inorganic } \\
\text { phosphorus fertilizer) }\end{array}$ & $\begin{array}{l}\text { Vegetation terminated with glyphosate herbicide two } \\
\text { weeks before planting and tilled to } 7 \text { to } 10 \mathrm{~cm} \text { deep } \\
\text { immediately before planting; Triple superphosphate } \\
(926 \mathrm{~kg} / \mathrm{ha}, 45 \% \mathrm{P}) \text { incorporated with the tillage event }\end{array}$ \\
\hline 5 & Miscanthus & $\begin{array}{l}\text { Till + Biosolids } \\
\text { (Organic source of } \\
\text { phosphorus) }\end{array}$ & $\begin{array}{l}\text { Vegetation terminated with glyphosate herbicide two } \\
\text { weeks before planting and tilled to } 7 \text { to } 10 \mathrm{~cm} \text { deep } \\
\text { immediately before planting; } 45 \text { tons/ha biosolids } \\
(586 \mathrm{~kg} / \text { ha } \mathrm{P}) \text { incorporated with the tillage event }\end{array}$ \\
\hline
\end{tabular}

The initial soil screening and the detailed surface soil $\mathrm{Pb}$ distribution were performed using a portable X-ray fluorescence spectroscopy (Niton XL3t XRF analyzer, Billerica, MA, USA), $\mathrm{X}$-ray absorption spectroscopy (XAS) was used for $\mathrm{Pb}$ speciation [61]. The concentration of $\mathrm{Pb}$ measured in the soil before planting the Miscanthus ranged from 1000 to $1500 \mathrm{mg} / \mathrm{kg}$ (Table 2) [10].

Table 2. Aged $\mathrm{Pb}$ concentration in the Ft.-Riley old skeet range soil and dry matter yield of Miscanthus for each growing season 2016, 2017, and 2018 (mean \pm standard error mean for $\mathrm{N}=4$ ).

\begin{tabular}{ccccc}
\hline \multirow{2}{*}{ Treatment } & Concentration of $\mathbf{P b}(\mathbf{m g} / \mathbf{k g})$ & \multicolumn{3}{c}{ Biomass Yield $\left.\mathbf{( M g} / \mathbf{h a}^{-\mathbf{1}}\right)$} \\
\cline { 3 - 5 } & & $\mathbf{2 0 1 6}$ & $\mathbf{2 0 1 7}$ & $\mathbf{2 0 1 8}$ \\
\hline Control & $1093 \pm 103$ & $3.6 \pm 0.5$ & $2.0 \pm 0.2$ & $4.2 \pm 0.3$ \\
M-No-till & $1290 \pm 34$ & $7.0 \pm 1.4$ & $9.3 \pm 2.1$ & $8.0 \pm 0.9$ \\
M-Till & $1396 \pm 29$ & $9.6 \pm 1.0$ & $10.8 \pm 1.0$ & $6.9 \pm 0.7$ \\
M-TSP & $1457 \pm 42$ & $8.4 \pm 0.7$ & $9.8 \pm 0.6$ & $6.9 \pm 0.9$ \\
M-Biosolids & $1103 \pm 50$ & $13.5 \pm 1.0$ & $9.9 \pm 1.8$ & $10.5 \pm 1.5$ \\
LSD 0.05 $^{*}$ & 0.002 & $<0.001$ & $<0.001$ & $<0.001$ \\
HSD $^{1}$ & 262 & 3.8 & 4.9 & 3.9 \\
\hline
\end{tabular}

${ }^{1}$ Tukey's Honest Significant Difference for mean comparisons with an alpha $(\alpha)$ of 0.05 .

Analysis by X-ray fluorescence indicated that pyromorphite and ferroplumbite were the main species present. Because the concentrations were totals based on dry soil weight, belowground materials would have much lower $\mathrm{Pb}$.

Sampling for nematodes was conducted in the third year of plantation growth in 2018. This study was not specifically designed to examine the relationship between crop yield and soil nematode parameters. However, the three-year monitoring of dry yield indicated that in 2017 no significant differences were observed between Miscanthus treatments, which all produced significantly more 
biomass than the Control (Table 2), and in 2018 the differences were observed in between treated plots [10] resulted in the harvest values which was the biggest for plot treated by Biosolids (Table 2).

The soil at the Ft. Riley site is a Mollisol with silty clay loam texture, developed initially from loess and is of the Wymore series (fine, smectitic, mesic Aquertic Argiudoll) [62]. Samples to study the nematode community composition were obtained in spring and fall of 2018 from the experimental plots during the third season of Miscanthus growth. Determination of soil agrochemical properties followed the standard approaches [63]. The agrochemical properties of the soil are $\mathrm{pH}$ (1:10 soil: water) 6.85 , Cation exchange capacity $19.5 \mathrm{cmol}^{+} \mathrm{kg}$, sand-11.3\%, silt-59.8\%, and clay-28.9\%, Mehlich III-P $408.3 \mathrm{mg} / \mathrm{kg}$, Extractable K $589.5 \mathrm{mg} / \mathrm{kg}$.

\subsection{Soil Sampling, Nematode Isolation, Identification and Calculation of Community Structure Indicators}

Soil samples for nematode community analyses were collected with a $2 \mathrm{~cm}$ diameter stainless steel, soil core sampling probe to a depth of $15 \mathrm{~cm}$ from four replications of five experimental treatments in the spring (May 15) and fall (October 18) of the third growing season (2018) after imposing all agronomic practices in 2016. Ten cores at random intervals were taken in each plot and bulked for analysis. Miscanthus plants were no more than 0.6 to $0.9 \mathrm{~m}$ tall at the May 15 sampling and were approaching 2.2 to $2.5 \mathrm{~m}$ height at the October 18 sampling. At the time of nematode sampling, the Miscanthus had been in place for 24 and 29 months for the spring and fall samplings, respectively, and aboveground biomass had been harvested twice (December 2016 and December 2017). Hand weeding to remove plants invading from plot borders was the only management practice imposed after planting other than biomass harvest each year in early December.

Nematodes were extracted from $100 \mathrm{~cm}^{3}$ subsamples following the homogenization of composite soil samples collected from each experimental plot using a standard centrifugal-flotation technique [64]. Soil from the subsample was suspended in 41 of pressurized water, and the suspension was poured over an $850-\mu$-pore sieve nested over a 38 - $\mu$-pore sieve. The bottom sieve contents were centrifuged in a $45 \%$ sucrose solution for $1 \mathrm{~min}$ at $270 \mathrm{~g}$ using a Clay Adams Dynac centrifuge. The supernatant was rinsed over a $25-\mu$-pore sieve and collected for counting. A 1-mL aliquot of each sample was counted at 100x using a Chalex LLC precision chambered counting slide and an Olympus BX50 microscope. A minimum of 100 individuals per sample were identified to genus or family using the illustrated key by Tarjan et al. 1977 [65]. According to Yeates et al. [20] families were assigned to trophic groups, and maturity indices were calculated based on c-p classes $[15,16,20]$ Family-level resolution (which generally provides well-documented and reliable information related to the soil food web and soil processes) represents an acceptable compromise between trophic-level and genus-level (or species-level) resolution (for which there is very little documentation) [15]. Additionally, several important families of tallgrass prairie nematodes consist of numerous genera [47], often with limited abundance.

While calculating nematode abundance of family Tylenchidae, its abundance was divided 50-50 because nematodes from the family Tylenchidae can be assigned to the epidermal root hair feeders [20], and several genera can be assigned to fungal feeders [51,66]. In addition to total abundance and family richness, two indices were calculated to quantify diversity of the nematode community. The Shannon-Weaver diversity index ' $H$ ' [67] was calculated as follows:

$$
H=\sum_{i=1}^{S}\left(-1 \cdot p_{i} \cdot \log _{2} p_{i}\right) .
$$

The Pielou evenness index (I) [68] was calculated as follows:

$$
I=\frac{H}{\log _{2} S}
$$

In these formulas, $p_{i}$ is the proportion of the ith family individuals in the community, and $S$ is the total number of nematode families in the community. 
The MI was calculated as the weighted mean of the individual colonizers (c) and persisters (p) (c-p) values [69]:

$$
M I=\sum_{i=1}^{S}\left(v_{i} \cdot p_{i}\right),
$$

where $v_{i}$ is the c-p value of family $i$ as given in Ferris [15], and $p_{i}$ is the proportion of the individuals of the $i$-th family in the community.

\subsection{Statistical Analysis}

Multivariate General Linear Models were used to test the significance of the impact of applied agronomic practices to nematode communities (Software package STATISTICA). Two multivariate GLMs were performed with the season (two levels), agronomic treatment (five levels) and season $\times$ treatment (interaction) as categorical predictors and with crop yield as a continuous predictor. One MGLM with the set of nematode families and another MGLM with the set of community indices as the multivariate dependent variable were performed with differences between individual treatments tested using a Planned Comparison.

\section{Results}

Twenty-one nematode taxa were identified in soil under Miscanthus established using the four agronomic practices: seven herbivores, six fungivores, four bacterivores, and four omnivore-predators; whereas in the Control, one additional family, Meloidogynidae, was found. Nematode abundance ranged from 383 to 4049 individuals/100 $\mathrm{g}$ of soil (Figure 1). The most abundant group across five treatments, including the Control, was herbivores with eight taxa, followed by fungivores with six taxa. The family Haplolaimidae, belonging to herbivores, was dominant across all treatments in total and relative abundance. Among all taxa across treatments, including the Control, the highest abundance of 1522 individuals/100 $\mathrm{g}$ of soil and $61 \%$ of relative abundance was found for Haplolaimidae.Haplolaimidae total abundance and relative abundance were greatest in Till+biosolids and 12-fold less in the Control (135 individuals/100 g of soil and 18\%).

Multivariate GLMs showed that agronomic treatments and sampling time significantly influenced nematode assemblage (Table 3). The interaction of these predictors and crop yield in the current and previous years did not have a significant impact. However, these predictors were statistically significant in a model where only crop yields were predictors. The factor of the crop yield in the model, without taking into account the agronomic effects and season, had an impact on bacterivores and most herbivores; however, an impact of yield on the abundance of fungivores and omnivore/predators was not found. The influence was mainly found with the current year yield; nevertheless, the influence of the previous year's yield was also observed in some cases.

The seasonal factor had a significant effect on the community structure (GLM planned comparison, $F=5.83, p=0.005)$. In May, the abundance of Rhabditidae and Aphelenchidae was significantly greater than in October, while in October, the abundance of Xiphinematidae, Tylencholaimidae, Aporcelaimidae, Mononchidae, Nordiidae, Qudsianematidae was significantly higher than in May (Table 4). The nematode community in the No-till treatment was different from the Control conditions (GLM planned comparison, $F=5.83, p=0.022$ ). The No-till treatment reduced the abundance of Pratylenchidae, Plectidae, Prismatolaimidae, and Tylencholaimidae. The Till treatment impacted the nematode community as well (GLM planned comparison, $F=2.63, p=0.049$ ) by reducing the abundance of Pratylenchidae and Plectidae compared to the Control. No-till and Till treatments differently impacted family composition of the nematode community (GLM planned comparison, $F=4.93, p=0.004)$. 


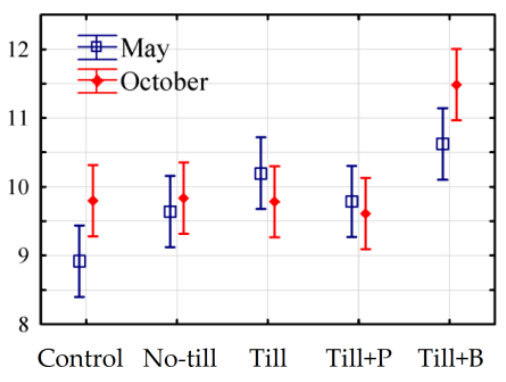

Total abundance

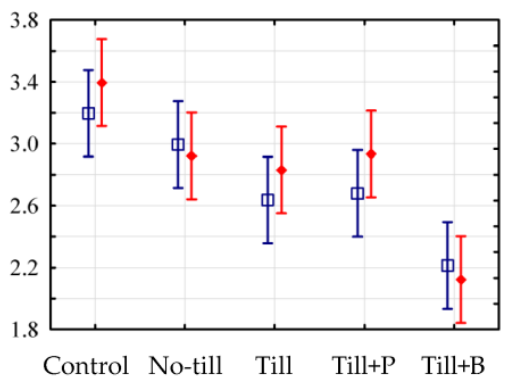

Shannon-Wiener diversity index
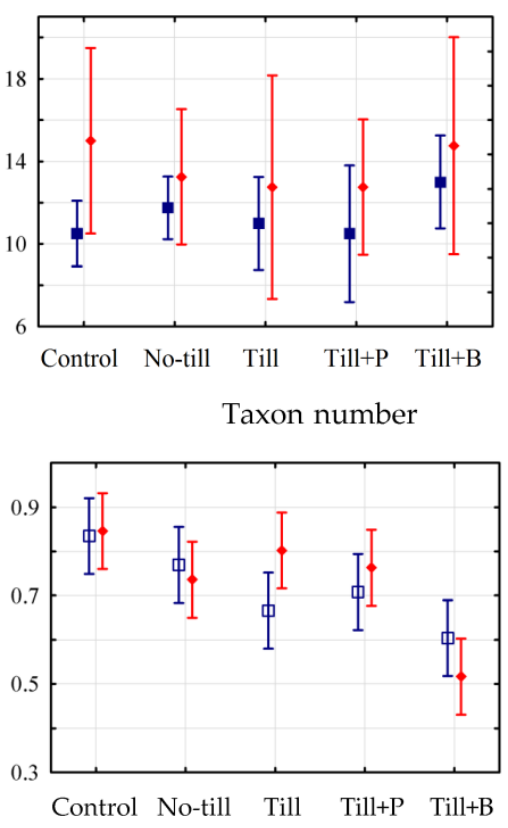

Pielou diversity index

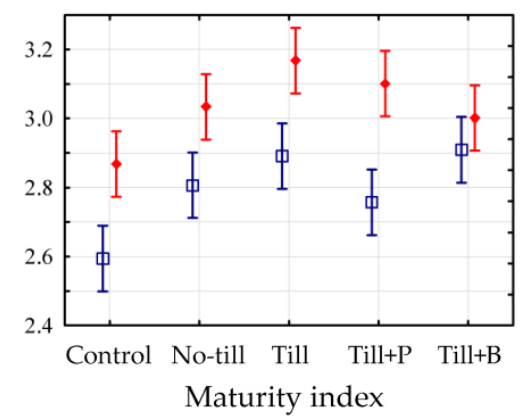

Figure 1. Total abundance (log2-transformed), taxon number, Shannon-Wiener diversity index, Pielou diversity index, and Maturity index of nematode communities (mean and $95 \%$ confidence intervals) as a response to agronomic treatments.

Table 3. Multivariate GLM results examining the effect of treatment type, season and crop yield as continuous predictor on nematode assemblage composition.

\begin{tabular}{|c|c|c|c|c|c|c|}
\hline Effect & Wilks-Lambda & F-Ratio & $\begin{array}{l}\text { Effect Degrees } \\
\text { of Freedom }\end{array}$ & $\begin{array}{l}\text { Error Degrees } \\
\text { of Freedom }\end{array}$ & $p$-Level & $\begin{array}{c}\text { Effect } \\
\text { Size }\left(\eta^{2}\right)\end{array}$ \\
\hline \multicolumn{7}{|c|}{ Agronomic practices, season, crop yield } \\
\hline Intercept & 0.058 & 5.14 & 22 & 7.00 & 0.017 & 0.94 \\
\hline Treatment (T) & 0.00004 & 4.08 & 88 & 30.15 & $<0.001$ & 0.92 \\
\hline Sampling time (M) & 0.074 & 3.95 & 22 & 7.00 & 0.034 & 0.93 \\
\hline $\mathrm{T}^{*} \mathrm{M}$ & 0.0013 & 1.48 & 88 & 30.15 & 0.11 & 0.81 \\
\hline Yield 2018 & 0.31 & 0.70 & 22 & 7.00 & 0.75 & 0.67 \\
\hline Yield 2017 & 0.18 & 1.44 & 22 & 7.00 & 0.32 & 0.82 \\
\hline \multicolumn{7}{|c|}{ Yield only } \\
\hline Intercept & 0.04 & 16.00 & 22 & 16 & $<0.001$ & 0.96 \\
\hline Yield 2018 & 0.18 & 3.42 & 22 & 16 & 0.007 & 0.83 \\
\hline Yield 2017 & 0.23 & 2.40 & 22 & 16 & 0.039 & 0.77 \\
\hline
\end{tabular}

Compared to the No-till treatment, Till resulted in increased abundance of such families as Prismatolaimidae and Qudsianematidae. The application of P, together with Till (T3), changed the nematode community (GLM planned comparison, $F=2.67, p=0.047$ ). Till processing alone is manifested in the Pratylenchidae and Prismatolaimidae abundances. The application of biosolids changed the nematode community structure more than the application of Till only (GLM planned 
comparison, $F=4.27, p=0.008)$. This is reflected in the increasing abundance of families Haplolaimidae, Telotylenchidae, Criconematidae, Pratylenchidae, Xiphinematidae, and Belondiridae and in the decrease in abundance of families Anguinidae, Aphelenchidae, Prismatolaimidae, Tylencholaimidae, Diptherophoridae, and Mononchidae. The community response to Biosolids application compared with the response of using $\mathrm{P}$ is similar to the Biosolids application compared with Till processing only (GLM planned comparison, $F=8.95, p<0.001$ ).

Table 4. Response of given nematode taxa abundance to agronomic practices, season, and crop yield (from two multivariate GLMs).

\begin{tabular}{|c|c|c|c|c|c|c|c|c|c|c|c|c|}
\hline \multirow{3}{*}{ Taxon } & \multirow{3}{*}{$c-p^{1}$} & \multicolumn{8}{|c|}{ Agronomic Practices, Season, and Crop Yield ${ }^{2}$} & \multicolumn{3}{|c|}{ Yield Only } \\
\hline & & \multicolumn{7}{|c|}{ Planned Comparison $^{3}$} & \multirow{2}{*}{$R^{2}$} & \multicolumn{2}{|c|}{ Year } & \multirow{2}{*}{$R^{2}$} \\
\hline & & T0/T1 & T0/T2 & T1/T2 & T2/T3 & $\mathrm{T} 2 / \mathrm{T} 4$ & $\mathrm{~T} 3 / \mathrm{T} 4$ & M/O & & 2018 & 2017 & \\
\hline \multicolumn{13}{|c|}{ Bacterivores } \\
\hline Cephalobidae & 2 & - & - & - & - & - & - & - & 0.48 & $\downarrow$ & $\downarrow$ & 0.39 \\
\hline Plectidae & 2 & $\downarrow$ & $\downarrow$ & - & - & - & - & - & 0.47 & $\downarrow$ & $\downarrow$ & 0.38 \\
\hline Prismatolaimidae & 3 & $\downarrow$ & - & $\downarrow$ & $\uparrow$ & $\uparrow$ & - & - & 0.58 & $\downarrow$ & - & 0.36 \\
\hline \multirow{2}{*}{\multicolumn{13}{|c|}{ Herbivores }} \\
\hline & & & & & & & & & & & & \\
\hline Aphelenchoididae & 2 & - & - & - & - & - & - & - & - & - & - & - \\
\hline Belondiridae & 5 & - & - & - & - & $\downarrow$ & $\downarrow$ & - & 0.78 & $\uparrow$ & - & 0.25 \\
\hline Criconematidae & 3 & - & - & - & - & $\downarrow$ & $\downarrow$ & - & 0.63 & $\uparrow$ & - & - \\
\hline Hoplolaimidae & 3 & - & - & - & - & $\downarrow$ & $\downarrow$ & - & 0.85 & $\uparrow$ & - & 0.39 \\
\hline Meloidogynidae & 3 & - & - & - & - & - & - & - & - & - & - & 0.25 \\
\hline Pratylenchidae & 3 & $\downarrow$ & $\downarrow$ & - & $\downarrow$ & $\downarrow$ & $\downarrow$ & - & 0.60 & $\uparrow$ & - & - \\
\hline Telotylenchidae & 3 & - & - & - & - & $\downarrow$ & $\downarrow$ & - & 0.55 & $\uparrow$ & - & - \\
\hline Xiphinematidae & 5 & - & - & - & - & $\downarrow$ & $\downarrow$ & $\downarrow$ & 0.72 & - & $\downarrow$ & 0.23 \\
\hline \multicolumn{13}{|c|}{ Fungivores } \\
\hline Anguinidae & 3 & - & - & - & - & $\uparrow$ & $\uparrow$ & - & - & - & - & - \\
\hline Aphelenchidae & 2 & - & - & - & - & $\uparrow$ & $\uparrow$ & $\uparrow$ & 0.47 & - & - & - \\
\hline Diptherophoridae & 3 & - & - & - & - & $\uparrow$ & - & - & 0.53 & - & - & - \\
\hline Leptonchidae & 4 & - & - & - & - & - & - & - & - & - & - & - \\
\hline Tylenchidae & 2 & - & - & - & - & - & - & - & - & - & - & - \\
\hline Tylencholaimidae & 4 & $\downarrow$ & - & - & - & $\uparrow$ & $\uparrow$ & $\downarrow$ & 0.57 & - & - & - \\
\hline \multicolumn{13}{|c|}{ Omnivore/predators } \\
\hline Aporcelaimidae & 5 & - & - & - & - & - & - & $\downarrow$ & 0.66 & - & - & - \\
\hline Mononchidae & 4 & - & - & - & - & $\uparrow$ & - & $\downarrow$ & 0.48 & - & - & - \\
\hline Nordiidae & 4 & - & - & - & - & - & $\uparrow$ & $\downarrow$ & 0.75 & - & - & - \\
\hline Qudsianematidae & 4 & - & - & $\downarrow$ & - & - & - & $\downarrow$ & 0.71 & - & - & - \\
\hline
\end{tabular}

There is a decrease in the abundance of Nordiidae under the influence of Biosolids but no difference in abundance of Diptherophoridae and Mononchidae. The agronomic treatments and sampling season had a statistically significant impact on the nematode community (Table 5), but the interaction of these factors and crop yields did not affect synecological characteristics. 
Table 5. Multivariate GLM results examining the effect of treatment type, season, and crop yield as continous predictor on nematode assemblage synecological parameters.

\begin{tabular}{|c|c|c|c|c|c|c|}
\hline Effect & $\begin{array}{l}\text { Wilk's } \\
\text { Lambda }\end{array}$ & F-Ratio & $\begin{array}{l}\text { Effect Degrees } \\
\text { of Freedom }\end{array}$ & $\begin{array}{l}\text { Error Degrees } \\
\text { of Freedom }\end{array}$ & $p$-Level & $\begin{array}{c}\text { Effect } \\
\text { Size }\left(\eta^{2}\right)\end{array}$ \\
\hline \multicolumn{7}{|c|}{ Agronomic practices, season, crop yield } \\
\hline Intercept & 0.0039 & 658.6 & 8 & 21.00 & $<0.001$ & 0.99 \\
\hline Treatment (T) & 0.091 & 2.25 & 32 & 79.04 & $<0.001$ & 0.48 \\
\hline Sampling time (M) & 0.16 & 14.01 & 8 & 21.00 & $<0.001$ & 0.84 \\
\hline $\mathrm{T}^{*} \mathrm{M}$ & 0.22 & 1.25 & 32 & 79.04 & 0.21 & 0.34 \\
\hline Yield 2018 & 0.92 & 0.13 & 8 & 21.00 & 0.99 & 0.047 \\
\hline Yield 2017 & 0.88 & 0.34 & 8 & 21.00 & 0.94 & 0.11 \\
\hline \multicolumn{7}{|c|}{ Yield only } \\
\hline Intercept & 0.0019 & 1926.2 & 8 & 30 & $<0.001$ & 0.99 \\
\hline Yield 2018 & 0.78 & 1.04 & 8 & 30 & 0.45 & 0.19 \\
\hline Yield 2017 & 0.81 & 0.90 & 8 & 30 & 0.53 & 0.22 \\
\hline
\end{tabular}

The seasonal factor had a statistically significant effect on the community synecological parameters (GLM planned comparison, $F=14.01, p<0.001$ ). The value of the Shannon diversity index was greater for samples collected in October compared with values for samples collected in May (Figure 1), which was due to an increase in the number of taxa, as statistically significant seasonal differences in the Pielou index were not revealed (Table 6).

Table 6. Response of nematode community synecological parameters to agronomic practices, season, and crop yield (from two multivariate GLMs).

\begin{tabular}{|c|c|c|c|c|c|c|c|c|c|c|c|}
\hline \multirow{3}{*}{ Taxon } & \multicolumn{8}{|c|}{ Agronomic Practices, Season of Sampling, and Crop Yield ${ }^{1}$} & \multicolumn{3}{|c|}{ Yield only } \\
\hline & \multicolumn{7}{|c|}{ Planned Comparison $^{2}$} & \multirow{2}{*}{$R^{2}$} & \multicolumn{2}{|c|}{ Year } & \multirow{2}{*}{$R^{2}$} \\
\hline & T0/T1 & T0/T2 & $\mathrm{T} 1 / \mathrm{T} 2$ & T2/T3 & T2/T4 & T3/T4 & M/O & & 2018 & 2017 & \\
\hline \multicolumn{12}{|c|}{ Diversity indexes and abundance } \\
\hline Family richness & - & - & - & - & - & - & $\downarrow$ & - & - & - & - \\
\hline Shannon diversity & - & $\uparrow$ & - & - & - & $\uparrow$ & $\downarrow$ & 0.59 & - & - & 0.26 \\
\hline Pielou diversity & $\uparrow$ & $\uparrow$ & - & - & $\uparrow$ & $\uparrow$ & - & 0.72 & $\downarrow$ & - & 0.25 \\
\hline Maturity index & $\downarrow$ & $\downarrow$ & - & - & - & - & $\downarrow$ & 0.87 & - & - & - \\
\hline Total abundance & - & $\downarrow$ & - & - & $\downarrow$ & $\downarrow$ & - & 0.69 & - & - & - \\
\hline \multicolumn{12}{|c|}{ Trophic groups } \\
\hline Bacterivores & - & - & - & - & - & - & - & - & $\downarrow$ & - & 0.27 \\
\hline Fungivores & - & - & - & - & $\uparrow$ & $\uparrow$ & - & 0.70 & - & - & - \\
\hline Herbivores & $\downarrow$ & $\downarrow$ & - & - & $\downarrow$ & $\downarrow$ & - & 0.79 & $\downarrow$ & - & 0.18 \\
\hline Omnivore/predators & - & - & - & - & - & - & $\downarrow$ & 0.60 & - & - & - \\
\hline
\end{tabular}

${ }^{1}$ Impact of the crop was statistically insignificant for all synecological parameters, so the relevant terms were completely omitted; ${ }^{2}$ T0-Control, T1-No-till, T2-Till, T3-Till+P, T4-Till+biosolids; M-May, O-October; for Planned comparison: $\downarrow$-by results of planned comparison the abundance of taxa increases under the influence of the second member from a pair of contrasts $(p<0.05)$; $\uparrow$ - by the results of planned comparison the abundance of taxa increases under the influence of the first member from a pair of contrasts $(p<0.05)$, for yield only model: $\downarrow$-parameter decrease due to yield increase $(p<0.05)$.

The Maturity Index also was greater in October, mainly due to an increase in omnivore/predators (Figure 2). The application of No-till technology did not affect the nematode community's synecological characteristics compared to Control (GLM planned comparison, $F=1.34, p=0.28$ ). However, some synecological indicators were sensitive to this impact. Thus, No-till technology led to a reduction of the Pielou index, to an increase of the Matrix index, and to an increase in the role of the trophic structure of herbivores. Till treatment did not significantly impact synecological indicators (GLM planned comparison, $F=2.28, p=0.06$ ). However, it led to a decrease in the Shannon diversity index, mainly due to the evenness of the abundance of nematode families, rather than the number of families, as indicated by a consistent decrease in the Pielou index. The decrease in abundance evenness of families occurred against the background of increasing in the total community size. This increase in 
community size was due to the growth of a limited number of nematode families that belonged to the herbivores trophic group.

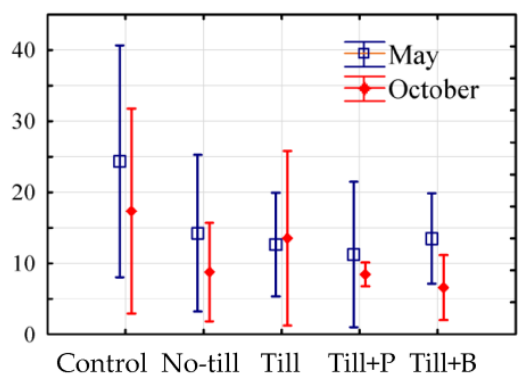

Bacterivores

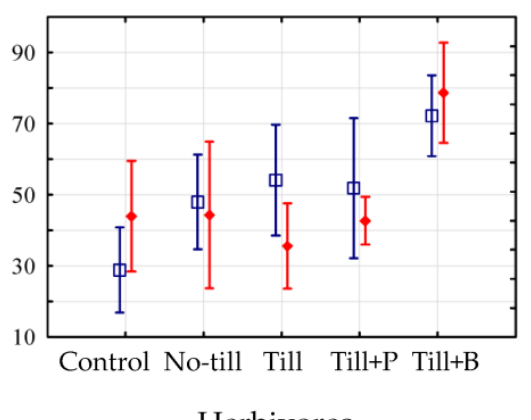

Herbivores
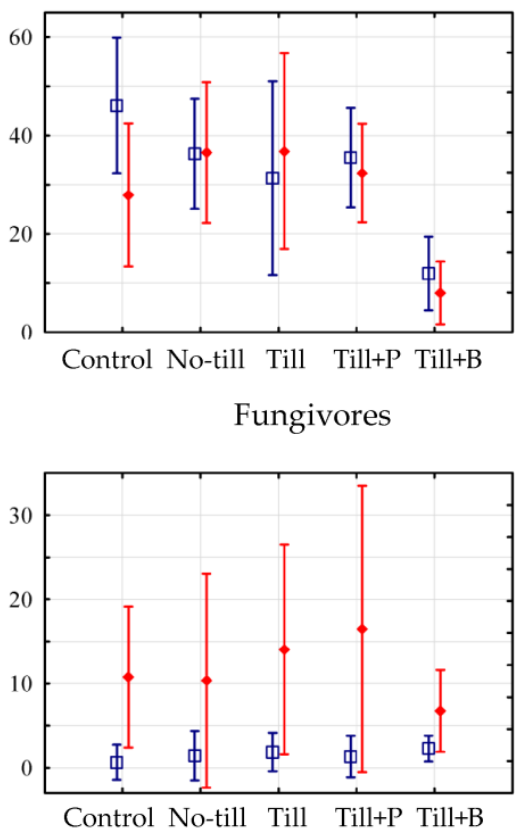

Omnivore/Predators

Figure 2. Proportion of the trophic groups in the nematode communities (in \%, mean and 95\% confidence intervals) as a response to different treatments.

No-till and Till treatment did not have different impacts on the nematode community synecological parameters (GLM planned comparison, $F=0.50, p=0.84$ ). The application of P compared with the Till only treatment, did not affect the variability of synecological parameters (GLM planned comparison, $F=0.26, p=0.97$ ). In turn, the impact of Biosolids application was significant (GLM planned comparison, $F=4.58, p=0.002$ ). The application of Biosolids led to a decrease in the Pielou index values and to decrease in the fungivores proportion in the trophic community structure, and to increase in the total community size and herbivores proportion compared to Till only. The application of Biosolids and $P$ treatment differed significantly in the impact on the synecological characteristics of the nematode community (GLM planned comparison, $F=4.58, p=0.002$ ).

\section{Discussion}

Lead is a highly persistent toxic trace element, and $\mathrm{Pb}$ contaminated soil remediation presents several challenges [70]. Soils contaminated with trace elements, including $\mathrm{Pb}$, may not be suitable for growing human or animal plant food, depending on concentration and speciation. Conservation reserve of contaminated land may be one of the solutions to this problem, but this approach may remove large areas from economic use. Also, the immobilization processes of toxicants can be slowed in semi-natural plant communities formed after conservation. Miscanthus cultivation on contaminated land is more effective, and in addition to the production of biomass, it also contributes to soil organic matter accumulation [26]. It should be noted that the dynamics of organic matter in the soil is a complex phenomenon, the consequences of which can be observed only over a considerable period of time. Thus, nematode community assessment provides an opportunity for real-time monitoring of organic matter transformation processes associated with soil health change under long-term cultivation of Miscanthus.

Significant transformations in the trophic group structure occurred under Miscanthus cultivation compared to the mixed plant cover. Besides the decrease of nematode diversity, the increase of plant-feeding nematodes was observed. These results are in line with several studies showing the 
effect of plant composition change on shifts in nematode communities [71-74] and the patterns in nematode abundance and diversity among habitats related to plant community and soil traits [75]. It has been shown that natural ecosystems are characterized by the highest values of nematode taxonomic richness [76-78]. The conversion of natural habitats to long-term monoculture reduced trophic diversity, with a low relative abundance of predators or omnivores [79], and an increase in the proportion of herbivores [80]. The declining diversity and increase of plant-feeders are most likely because the native vegetation is resistant to disturbance, including nematode parasitism, compared to plants grown in farming systems [81]. When a crop grows in monoculture, herbivores' negative effect is generally increased, while the tolerance to parasitism is decreased [82]. Nematode community structure (e.g., family relative abundances) varies across the tallgrass prairie [40]. The structure observed for the native plots in this study is within the range of those observed for nematode communities in uncontaminated tallgrass prairie generally $[40,83]$, and similar to that reported for uncontaminated areas on Fort Riley [62].

The results indicated the differential sensitivity of nematode taxa to the various types of agronomic practices. To explain the observed effects, we considered the influence of external factors in agronomic practices on the nematode community composition. These factors can directly affect a particular taxon's living conditions and thus determine the patterns of their dynamics. External influences can also be triggered by endogenous mechanisms that modulate intra-community interactions, resulting in pattern dynamics due to successive assemblage dynamics. Such patterns, induced by intra-community mechanisms, may be formally independent of external influences at later development stages. To analyze the nematode community composition, the synecological indicators, such as abundance, diversity and community functional status, characterize the community. Indicative characteristics of nematode communities were applied to the best optimal agronomic practices in crop management that united the goal of obtaining the highest crop yield with achieving the highest contaminant immobilization effect by Miscanthus cultivation. Results revealed that the agronomic practices had a significant impact on the nematode community structure. This observation confirms the results of Porazinska et al. [84], who documented that agricultural practices and cropping systems influence nematodes, which are used widely as indicators of soil health.

The slowest reproducing nematode group (omnivores/predators, some fungivores and herbivores with c-p index 4 and 5) exhibited greatest change between seasons. The auturm (October) populations are completely typical of omnivore/preditor relative abundances in tallgrass prairie. According to 'Shelford's Law of Tolerance', all populations staying in the optimal condition do not demonstrate an unambiguous response to the ecological factors. In contrast, switching the ecological factor from the pessimum to the optimum is commonly accompanied by the populations' sensitive reaction. In our case, nematodes with low c-p indexes were closer to the optimum zone than those with high c-p indexes. The current study showed that the abundance of omnivorous/predator populations was lower compared to other trophic groups. Thus, omnivore/predators responded by population increases as they approached optimum conditions in autumn, while other trophic groups did not show this trend.

In our research, the nematode assemblage of the undisturbed Control (mixed plant cover presented by alfalfa, grass and forbes) was characterized by the relatively higher taxonomic diversity. The Shannon Diversity Index is sensitive to two aspects of taxon diversity: quantity and evenness of its number. In turn, the Pielou index reflects only one aspect of diversity-evenness. The results showed a high correlation between these factors, which indicated that the changing abundance of different taxa was a significant source in nematode diversity variability.

The relatively higher taxonomic diversity in the control condition was observed due to a significant number of taxa inhabiting control conditions being adversely affected by agronomic practices. Nematode diversity in the control plots was likely primarily driven by plant diversity and heterogeneity. Miscanthus monoculture clearly reduced diversity and/or affected MI, with the biosolid treatment reducing diversity even further. Conversely, taxa that find favorable living conditions in the face of agro-technological impacts showed a rapid increase in numbers. The observed transitions had 
a distinct effect on the variation of the trophic structure of the group. Thus, a lower abundance and a relatively high level of fungivores were seen in the controls compared to plots where Miscanthus was grown. This observation fits with a previous finding that Kansas prairies are relatively rich in nematode diversity $[40,62,83]$.

Bacterivorous and fungivorous are involved in decomposition that releases nitrogen and provides soil fertility. The current study showed that bacterivores are the most conserved component of the nematode community's trophic structure. Unlike other trophic groups, they are resistant to the applied agronomic practices that form homogeneous clusters that correspond to a specific agronomic 'factor's influence. However, several previous studies indicated that bacteriovores were at least slightly stimulated by tillage [85]. Thus, the overall abundance of nematodes in response to biosolids' addition is due to the increase in the population of herbivores, and omnivore/predators had the most favourable conditions in the No-till treatment. This finding contradicts Bulluck et al. [86], who showed that tillage did not impact free-living and plant-parasitic nematode assemblages, but animal manure and plant compost had larger effects on bacterivores and fungivores compared to synthetic fertilizers.

The results demonstrated that the application of biosolids (organic phosphorus) affected the nematode community significantly due to the herbivore increase, whereas no powerful effect was observed related to bacterivores. This contradicts the research of $\mathrm{Li}$ et al. [87] that showed a negative impact of fresh and dried domestic and fresh industrial sludge on the secondary consumers-bacterivores. In their research, the organic matter input associated with the manure treatment led to faster increases in bacterial abundance than fungal abundance [88]. That observation may explain the findings of the current study that agronomic practices mainly stimulated the bacterivores' growth compared to fungivores. This result is crucial because high bacterial abundance contributes prominently to SOC turnover, the liberation of nutrients, and overall soil quality [89]. Following calibration, the MI generally decreases under the influence of soil disturbance. However, in our study, the index increased in both Till and No-till treatments. That may be because soil tillage was performed two years before the nematode sampling. After two years of plantation growth, an expected negative influence of soil disturbance on the MI may be compensated by an additional amount of organic matter supplied by Miscanthus during production in the field. Miscanthus is an essential factor contributing to the stabilization of physical soil conditions [1,2]. The nematode community response of increasing MI is most likely due to an additional amount of organic matter and stabilization of the soil physical conditions during Miscanthus multi-year growth. However, little is known about changes in the nematode community in Miscanthus systems, and long-term, in-depth research is needed to enhance our understanding.

The current study results demonstrate that the nematode community was more strongly affected by adding tillage than by the organic matter amendment. The abundance of the nematode assemblage increased in the Till treatment due to more herbivores than in the No-till treatment, where the assemblage increased its abundance mainly due to omnivore/predators. This finding agrees with Zhong et al. [45], who reported that No-till and Reduced-till practices increased overall nematode abundance through increasing the abundance of persisters indicated by increasing MI. The finding is also confirmed by the results of Bongiorno et al. [90], who observed that reducing or minimizing tillage contributed to the formation of more stable conditions for the existence of nematode communities, naturally reflected in MI increasing.

\section{Conclusions}

The evaluation of the nematode community structure in the Pb-contaminated aged soil in Ft.Riley Military Reservation, USA, was performed in spring (May) and autumn (October) during the third year of Miscanthus multi-year growth. Before Miscanthus plantation establishment, the different agronomic practices (No-till, Till) and soil amendments (Phosphorous fertilizes, Biosolids) were applied to evaluate how establishment methods and soil amendments affect Miscanthus growth, soil organic carbon processes, and bioavailability of $\mathrm{Pb}$. Multivariate General Linear Models (MGLMs) were used 
to interpret the results of nematodes community evaluation and to determine the influence of soil treatment and amendments on nematode community composition. The obtained results showed that the nematode community Pielou diversity index was lower for the Control case (without any agronomic practices) compared to all treatments including Miscanthus, mainly due to decreased herbivores. The abundance and MI of the nematode community showed a tendency to increase, which can be explained by increasing the organic matter and soil stabilization with multiple years of growth of Miscanthus and the stabilization effect of the crop on the habitat of the nematode community.

Among different agronomic practices utilized for crop establishment at the research site, two cases, namely Till and Till+biosolids, affected the nematode community. The overall finding confirmed that soil nematode community structure could be used as a sensitive indicator of ecological processes in the soil during Miscanthus cultivation on Pb-contaminated aged land. Further research will elucidate the association of nematode community, namely bacterivores and fungivores, responsible for decomposition channels and soil organic carbon under soil treatments in a multi-year Miscanthus plantation established at Pb-contaminated aged soil, Ft.Riley Military Reservation. Future planned comparison of nematode monitoring during multiyear crop production would help to define the herbivores' contribution to Miscanthus crop yield reduction in long-term research and to look deeply to the role of various soil amendments and agricultural practices.

Author Contributions: Conceptualization, T.T. and T.S. and V.P.; methodology, T.T. and G.M.H. and T.S.; software, O.Z.; validation, T.T. and T.S.; formal analysis, T.T. and G.M.H. and T.S.; investigation, Z.A. and T.T. and K.R.; resources, T.T. and G.M.H.; data curation, T.S. and L.D.; writing-original draft preparation, T.S. and V.P. and L.D.; writing-review and editing T.S. and V.P. and L.E. and L.D. and K.R.; visualization, Z.A. and T.S. and O.Z.; supervision, G.M.H. and K.R.; project administration, V.P.; funding acquisition, G.M.H. and V.P. and L.E. All authors have read and agreed to the published version of the manuscript.

Funding: The research was supported by NATO SPS MYP \#G4687, Contribution no. 20-242-J from the Kansas Agricultural Experiment Station, U.S.A, and Internal grant agency of J.E.Purkyne University, Czech Republic, grant UJEP-IGA-TC-2019-44-01-2.

Acknowledgments: We would like to acknowledge the Kansas Agricultural Experiment Station, U.S.A. for technical support \& contribution in kind and Ethan N. Doung, Canada for assistance with proof reading.

Conflicts of Interest: The authors report no competing interests either financially or otherwise.

\section{References}

1. Lewandowski, I.; Clifton-Brown, J.; Kiesel, A.; Hastings, A.; Iqbal, Y. Miscanthus. In Perennial Grasses for Bioenergy and Bioproducts; Alexopoulou, E., Ed.; Academic Press, Elsevier: Cambridge, MA, USA, 2018; pp. 35-59.

2. Roozeboom, K.L.; Wang, D.; McGowan, A.R.; Propheter, J.L.; Staggenborg, S.A.; Rice, C.W. Long-term Biomass and Potential Ethanol Yields of Annual and Perennial Biofuel Crops. Agron. J. 2019, 111, 74-83. [CrossRef]

3. Nsanganwimana, F.; Pourrut, B.; Mench, M.; Douay, F. Suitability of Miscanthus species for managing inorganic and organic contaminated land and restoring ecosystem services. A review. J. Environ. Manag. 2014, 143, 123-134. [CrossRef]

4. Xue, S.; Lewandowski, I.; Wang, X.; Yi, Z. Assessment of the production potentials of Miscanthus on marginal land in China. Renew. Sustain. Energy Rev. 2016, 54, 932-943. [CrossRef]

5. Von Cossel, M.; Lewandowski, I.; Elbersen, B.; Staritsky, I.; Van Eupen, M.; Iqbal, Y.; Mantel, S.; Scordia, D.; Testa, G.; Cosentino, S.L.; et al. Marginal Agricultural Land Low-Input Systems for Biomass Production. Energies 2019, 12, 3123. [CrossRef]

6. Dražić, G.; Milovanović, J.; Stefanović, S.; Petrić, I. Potential of Miscanthus $\times$ giganteus for Heavy Metals Removing from Industrial Deposol. Acta Reg. Environ. 2018, 14, 56-58. [CrossRef]

7. Wanat, N.; Austruy, A.; Joussein, E.; Soubrand, M.; Hitmi, A.; Gauthier-Moussard, C.; Lenain, J.F.; Vernay, P.; Munch, J.C.; Pichon, M. Potentials of Miscanthus $\times$ giganteus grown on highly contaminated Technosols. J. Geochem. Explor. 2013, 126, 78-84. [CrossRef] 
8. Pidlisnyuk, V.; Shapoval, P.; Zgorelec, Ž.; Stefanovska, T.; Zhukov, O. Multiyear phytoremediation and dynamic of foliar metal(loid)s concentration during application of Miscanthus $\times$ giganteus Greef et Deu to polluted soil from Bakar, Croatia. Environ. Sci. Pollut. Res. 2020, 27, 31446-31457. [CrossRef]

9. Nurzhanova, A.; Pidlisnyuk, V.; Abit, K.; Nurzhanov, C.; Kenessov, B.; Stefanovska, T.; Erickson, L. Comparative assessment of using Miscanthus $\times$ giganteus for remediation of soils contaminated by heavy metals: A case of military and mining sites. Environ. Sci. Pollut. Res. 2019, 26, 13320-13333. [CrossRef]

10. Alasmary, Z. Laboratory-to Field-Scale Investigations to Evaluate Phosphate Amendments and Miscanthus for Phytostabilization of Lead-Contaminated Military Sites. Ph.D. Thesis, Kansas State University, Manhattan, KS, USA, 2020.

11. Sochová, I.; Hofman, J.; Holoubek, I. Using nematodes in soil ecotoxicology. Environ. Int. 2006, 32, $374-383$. [CrossRef] [PubMed]

12. Barker, K.R.; Koenning, S.R. Developing sustainable systems for nematode management. Annu. Rev. Phytopathol. 1998, 36, 165-205. [CrossRef]

13. Sánchez-Moreno, S.; Minoshima, H.; Ferris, H.; Jackson, L.E. Linking soil properties and nematode community composition: Effects of soil management on soil food webs. Nematology 2006, 8, 703-715. [CrossRef]

14. Sánchez-Moreno, S.; Ferris, H. Suppressive service of the soil food web: Effects of environmental management. Agric. Ecosyst. Environ. 2007, 119, 75-87. [CrossRef]

15. Ferris, H. Form and function: Metabolic footprints of nematodes in the soil food web. Eur. J. Soil Biol. 2010, 46, 97-104. [CrossRef]

16. Bongers, T.; Ferris, H. Nematode community structure as a bioindicator in environmental monitoring. Trends Ecol. Evol. 1999, 14, 224-228. [CrossRef] [PubMed]

17. Urzelai, A.; Hernández, A.J.; Pastor, J. Biotic indices based on soil nematode communities for assessing soil quality in terrestrial ecosystems. Sci. Total Environ. 2000, 247, 253-261. [CrossRef]

18. Neher, D.A. Role of nematodes in soil health and their use as indicators. J. Nematol. 2001, 33, 161-168.

19. Ferris, H.; Matute, M.M. Structural and functional succession in the nematode fauna of a soil food web. Appl. Soil Ecol. 2003, 23, 93-110. [CrossRef]

20. Yeates, G.W.; Bongers, T.; De Goede, R.G.; Freckman, D.W.; Georgieva, S.S. Feeding habits in soil nematode families and genera-an outline for soil ecologists. J. Nematol. 1993, 25, 315-331. [PubMed]

21. Briar, S.S.; Grewal, P.S.; Somasekhar, N.; Stinner, D.; Miller, S.A. Soil nematode community, organic matter, microbial biomass and nitrogen dynamics in field plots transitioning from conventional to organic management. Appl. Soil Ecol. 2007, 37, 256-266. [CrossRef]

22. Ritz, K.; Black, H.I.J.; Campbell, C.D.; Harris, J.A.; Wood, C. Selecting biological indicators for monitoring soils: A framework for balancing scientific and technical opinion to assist policy development. Ecol. Indic. 2009, 9, 1212-1221. [CrossRef]

23. DuPont, S.T.; Ferris, H.; Van Horn, M. Effects of cover crop quality and quantity on nematode-based soil food webs and nutrient cycling. Appl. Soil Ecol. 2009, 41, 157-167. [CrossRef]

24. Neher, D.A.; Olson, R.K. Nematode communities in soils of four farm cropping management systems. Pedobiologia 1999, 43, 430-438.

25. Ferris, H.; Bongers, T.; De Goede, R.G.M. A framework for soil food web diagnostics: Extension of the nematode faunal analysis concept. Appl. Soil Ecol. 2001, 18, 13-29. [CrossRef]

26. Hu, C.; Qi, Y. Effect of compost and chemical fertilizer on soil nematode community in a Chinese maize field. Eur. J. Soil Biol. 2010, 46, 230-236. [CrossRef]

27. D’Addabbo, T.; Papajová, I.; Sasanelli, N.; Radicci, V.; Renčo, M. Suppression of root-knot nematodes in potting mixes amended with different composted biowastes. Helminthologia 2011, 48, 278-287. [CrossRef]

28. Renčo, M.; Sasanelli, N.; D’Addabbo, T.; Papajová, I. Soil nematode community changes associated with compost amendments. Nematology 2010, 12, 681-692. [CrossRef]

29. Forge, T.A.; Bittman, S.; Kowalenko, C.G. Responses of grassland soil nematodes and protozoa to multi-year and single-year applications of dairy manure slurry and fertilizer. Soil Biol. Biochem. 2005, 37, 1751-1762. [CrossRef]

30. Leroy, B.L.M.M.; Bommele, L.; Reheul, D.; Moens, M.; De Neve, S. The application of vegetable, fruit and garden waste (VFG) compost in addition to cattle slurry in a silage maize monoculture: Effects on soil fauna and yield. Eur. J. Soil Biol. 2007, 43, 91-100. [CrossRef] 
31. Tian, G.; Granato, T.C.; Cox, A.E.; Pietz, R.I.; Carlson, C.R.; Abedin, Z. Soil Carbon Sequestration Resulting from Long-Term Application of Biosolids for Land Reclamation. J. Environ. Qual. 2009, 38, 61-74. [CrossRef] [PubMed]

32. Torri, S.I.; Corrêa, R.S.; Renella, G. Soil Carbon Sequestration Resulting from Biosolids Application. Appl. Environ. Soil Sci. 2014, 2014, 821768. [CrossRef]

33. Torri, S.; Corrêa, R.S.; Renella, G.; Vadecantos, A.; Perelomov, L. Biosolids Soil Application: Agronomic and Environmental Implications 2014. Appl. Environ. Soil Sci. 2015, 2015, 1-2. [CrossRef]

34. Mennan, S.; Melakeberhan, H. Effects of biosolid amendment on populations of Meloidogyne hapla and soils with different textures and pHs. Bioresour. Technol. 2010, 101, 7158-7164. [CrossRef]

35. Zasada, I.; Rogers, S.; Sardanelli, S. Application of alkaline-stabilised biosolids for Meloidogyne incognita suppression in microplots. Nematology 2007, 9, 123-129. [CrossRef]

36. Zasada, I.A.; Avendano, F.; Li, Y.C.; Logan, T.; Melakeberhan, H.; Koenning, S.R.; Tylka, G.L. Potential of an Alkaline-Stabilized Biosolid to Manage Nematodes: Case Studies on Soybean Cyst and Root-Knot Nematodes. Plant Dis. 2008, 92, 4-13. [CrossRef]

37. Yeates, G.W.; Speir, T.W.; Taylor, M.D.; Clucas, L.; Schaik, A.P. Nematode responses to biosolids incorporation in five soil types. Biol. Fertil. Soils 2006, 42, 550-555. [CrossRef]

38. Sarathchandra, S.U.; Ghani, A.; Yeates, G.W.; Burch, G.; Cox, N.R. Effect of nitrogen and phosphate fertilisers on microbial and nematode diversity in pasture soils. Soil Biol. Biochem. 2001, 33, 953-964. [CrossRef]

39. Liu, T.; Chen, X.; Hu, F.; Ran, W.; Shen, Q.; Li, H.; Whalen, J.K. Carbon-rich organic fertilizers to increase soil biodiversity: Evidence from a meta-analysis of nematode communities. Agric. Ecosyst. Environ. 2016, 232, 199-207. [CrossRef]

40. Todd, T.C. Effects of management practices on nematode community structure in tallgrass prairie. Appl. Soil Ecol. 1996, 3, 235-246. [CrossRef]

41. Rovira, A.D.; Simon, A. Growth, nutrition and yield of wheat in calcareous sandy loams of South Australia: Effects of soil fumigation, fungicide, nematicide and nitrogen fertilizers. Soil Biol. Biochem. 1985, 17, 279-284. [CrossRef]

42. Coyne, D.L.; Sahrawat, K.L.; Plowright, R.A. The influence of mineral fertilizer application and plant nutrition on plant-parasitic nematodes in upland and lowland rice in Côte d'Ivoire and its implications in long term agricultural research trials. Exp. Agric. 2004, 40, 245-256. [CrossRef]

43. Emery, S.M.; Reid, M.L.; Bell-Dereske, L.; Gross, K.L. Soil mycorrhizal and nematode diversity vary in response to bioenergy crop identity and fertilization. GCB Bioenergy 2017, 9, 1644-1656. [CrossRef]

44. Yeates, G.W.; Bongers, T. Nematode diversity in agroecosystems. Agric. Ecosyst. Environ. 1999, 74, $113-135$. [CrossRef]

45. Zhong, S.; Zeng, H.; Jin, Z. Influences of different tillage and residue management systems on soil nematode community composition and diversity in the tropics. Soil Biol. Biochem. 2017, 107, 234-243. [CrossRef]

46. Treonis, A.M.; Austin, E.E.; Buyer, J.S.; Maul, J.E.; Spicer, L.; Zasada, I.A. Effects of organic amendment and tillage on soil microorganisms and microfauna. Appl. Soil Ecol. 2010, 46, 103-110. [CrossRef]

47. De Goede, R.G.M.; Georgieva, S.S.; Verschoor, B.C.; Kamerman, J.W. Changes in nematode community structure in a primary succession of blown-out areas in a drift sand landscape. Fundam. Appl. Nematol. 1993, $16,501-513$.

48. Darby, B.J.; Todd, T.C.; Herman, M.A. High-throughput amplicon sequencing of rRNA genes requires a copy number correction to accurately reflect the effects of management practices on soil nematode community structure. Mol. Ecol. 2013, 22, 5456-5471. [CrossRef]

49. Zhao, J.; Neher, D.A. Soil nematode genera that predict specific types of disturbance. Appl. Soil Ecol. 2013, 64, 135-141. [CrossRef]

50. Wang, K.H.; McSorley, R.; Marshall, A.; Gallaher, R.N. Influence of organic Crotalaria juncea hay and ammonium nitrate fertilizers on soil nematode communities. Appl. Soil Ecol. 2006, 31, 186-198. [CrossRef]

51. Okada, H.; Harada, H.; Kadota, I. Fungal-feeding habits of six nematode isolates in the genus Filenchus. Soil Biol. Biochem. 2005, 37, 1113-1120. [CrossRef]

52. Lenz, R.; Eisenbeis, G. Short-term effects of different tillage in a sustainable farming system on nematode community structure. Biol. Fertil. Soils 2000, 31, 237-244. [CrossRef]

53. Shao, Y.; Zhang, W.; Shen, J.; Zhou, L.; Xia, H.; Shu, W.; Ferris, H.; Fu, S. Nematodes as indicators of soil recovery in tailings of a lead/zinc mine. Soil Biol. Biochem. 2008, 40, 2040-2046. [CrossRef] 
54. Park, B.Y.; Lee, J.K.; Ro, H.M.; Kim, Y.H. Short-term effects of low-level heavy metal contamination on soil health analyzed by nematode community structure. Plant Pathol. J. 2016, 32, 329-339. [CrossRef]

55. Šalamún, P.; Renčo, M.; Kucanová, E.; Brázová, T.; Papajová, I.; Miklisová, D.; Hanzelová, V. Nematodes as bioindicators of soil degradation due to heavy metals. Ecotoxicology 2012, 21, 2319-2330. [CrossRef]

56. Georgieva, S.S.; McGrath, S.P.; Hooper, D.J.; Chambers, B.S. Nematode communities under stress: The long-term effects of heavy metals in soil treated with sewage sludge. Appl. Soil Ecol. 2002, 20, $27-42$. [CrossRef]

57. Bakonyi, G.; Nagy, P.; Kádár, I. Long-term effects of heavy metals and microelements on nematode assemblage. Toxicol. Lett. 2003, 140, 391-401. [CrossRef]

58. Millward, R.N.; Grant, A. Pollution-induced tolerance to copper of nematode communities in the severely contaminated restronguet creek and adjacent estuaries, Cornwall, United Kingdom. Environ. Toxicol. Chem. 2000, 19, 454-461. [CrossRef]

59. Gutiérrez, C.; Fernández, C.; Escuer, M.; Campos-Herrera, R.; Beltrán Rodríguez, M.E.; Carbonell, G.; Rodríguez Martín, J.A. Effect of soil properties, heavy metals and emerging contaminants in the soil nematodes diversity. Environ. Pollut. 2016, 213, 184-194. [CrossRef]

60. Ekschmitt, K.; Korthals, G.W. Nematodes as Sentinels of Heavy Metals and Organic Toxicants in the Soil. J. Nematol. 2006, 38, 13-19.

61. US EPA. SW-846 Test Method 3051A: Microwave Assisted Acid Digestion of Sediments, Sludges, Soils, and Oils. Available online: https:/www.epa.gov/hw-sw846/sw-846-test-method-3051a-microwave-assistedacid-digestion-sediments-sludges-soils-and-oils (accessed on 19 September 2020).

62. Althoff, P.S.; Todd, T.C.; Thien, S.J.; Callaham, M.A. Response of soil microbial and invertebrate communities to tracked vehicle disturbance in tallgrass prairie. Appl. Soil Ecol. 2009, 43, 122-130. [CrossRef]

63. Bouyoucos, G.J. Hydrometer method improved for making particle size analyses of soils. Agron. J. 1962, 54, 464-465. [CrossRef]

64. Jenkins, W.R. A rapid centrifugal-flotation technique for separating nematodes from soil. Plant Dis. Report. 1964, 48, 692 .

65. Tarjan, A.C.; Esser, R.P.; Chang, S.L. An Illustrated Key to Nematodes Found in Fresh Water. J. WPCF 1977, $49,2318-2337$.

66. Okada, H.; Tsukiboshi, T.; Kadota, I. Mycetophagy in Filenchus misellus (Andrássy, 1958) Lownsbery \& Lownsbery, 1985 (Nematoda: Tylenchidae), with notes on its morphology. Nematology 2002, 4, 795-801. [CrossRef]

67. Shannon, C.E.; Weaver, W. The Mathematical Theory of Communication; The University of Illinois Press: Urbana, IL, USA, 1949.

68. Pielou, E.C. An Introduction to Mathematical Ecology; Wiley-Interscience: New York, NY, USA, 1969.

69. Bongers, T. The maturity index: An ecological measure of environmental disturbance based on nematode species composition. Oecologia 1990, 83, 14-19. [CrossRef]

70. Markus, J.; McBratney, A.B. A review of the contamination of soil with lead II. Spatial distribution and risk assessment of soil lead. Environ. Int. 2001, 27, 399-411. [CrossRef]

71. Li, Y.; Feng, J.; Chen, J.; Wu, J. Original vegetation type affects soil nematode communities. Appl. Soil Ecol. 2007, 35, 68-78. [CrossRef]

72. Schorpp, Q.; Schrader, S. Dynamic of nematode communities in energy plant cropping systems. Eur. J. Soil Biol. 2017, 78, 92-101. [CrossRef]

73. Krashevska, V.; Kudrin, A.A.; Widyastuti, R.; Scheu, S. Changes in Nematode Communities and Functional Diversity With the Conversion of Rainforest Into Rubber and Oil Palm Plantations. Front. Ecol. Evol. 2019, 7, 487. [CrossRef]

74. Yurkevich, M.G.; Sushchuk, A.A.; Matveeva, E.M.; Kalinkina, D.S. Changes in Soil Nematode Communities during Postagrogenic Transformation of Peat Soils and Vegetation. Eurasian Soil Sci. 2020, 53, 686-695. [CrossRef]

75. Wu, P.; Zhang, H.; Cui, L.; Wickings, K.; Fu, S.; Wang, C. Impacts of alpine wetland degradation on the composition, diversity and trophic structure of soil nematodes on the Qinghai-Tibetan Plateau. Sci. Rep. 2017, 7, 837. [CrossRef]

76. Freckman, D.W.; Ettema, C.H. Assessing nematode communities in agroecosystems of varying human intervention. Agric. Ecosyst. Environ. 1993, 45, 239-261. [CrossRef] 
77. Ekschmitt, K.; Bakonyi, G.; Bongers, M.; Bongers, T.; Boström, S.; Dogan, H.; Harrison, A.; Nagy, P.; O'Donnell, A.G.; Papatheodorou, E.M.; et al. Nematode community structure as indicator of soil functioning in European grassland soils. Eur. J. Soil Biol. 2001, 37, 263-268. [CrossRef]

78. Moura, G.S.; Franzener, G. Biodiversity of nematodes biological indicators of soil quality in the agroecosystems. Arq. Inst. Biol. 2017, 84, e0142015. [CrossRef]

79. Tomar, V.; Ahmad, W. Food web diagnostics and functional diversity of soil inhabiting nematodes in a natural woodland. Helminthologia 2009, 46, 183-189. [CrossRef]

80. Kimenju, J.W.; Karanja, N.K.; Mutua, G.K.; Rimberia, B.M.; Wachira, P.M. Nematode community structure as influenced by land use and intensity of cultivation. Trop. Subtrop. Agroecosyst. 2009, 11, 353-360.

81. Van der Putten, W.H. Plant defense belowground and spatiotemporal processes in natural vegetation. Ecology 2003, 84, 2269-2280. [CrossRef]

82. Li, X.; Ding, C.; Liu, J.; Zhang, T.; Wang, X. Evident Response of the Soil Nematode Community to Consecutive Peanut Monoculturing. Agron. J. 2015, 107, 195-203. [CrossRef]

83. Todd, T.C.; Powers, T.O.; Mullin, P.G. Sentinel nematodes of land-use change and restoration in tallgrass prairie. J. Nematol. 2006, 38, 20-27.

84. Porazinska, D.L.; Duncan, L.W.; McSorley, R.; Graham, J.H. Nematode communities as indicators of status and processes of a soil ecosystem influenced by agricultural management practices. Appl. Soil Ecol. 1999, 13, 69-86. [CrossRef]

85. Wardle, D.A.; Yeates, G.W.; Watson, R.N.; Nicholson, K.S. The detritus food-web and the diversity of soil fauna as indicators of disturbance regimes in agro-ecosystems. Plant Soil 1995, 170, 35-43. [CrossRef]

86. Bulluck, L.R.; Barker, K.R.; Ristaino, J.B. Influences of organic and synthetic soil fertility amendments on nematode trophic groups and community dynamics under tomatoes. Appl. Soil Ecol. 2002, 21, 233-250. [CrossRef]

87. Li, S.; Zhu, L.; Li, J.; Ke, X.; Wu, L.; Luo, Y.; Christie, P. Influence of long-term biosolid applications on communities of soil fauna and their metal accumulation: A field study. Environ. Pollut. 2020, 260, 114017. [CrossRef]

88. Jiang, Y.; Zhou, H.; Chen, L.; Yuan, Y.; Fang, H.; Luan, L.; Chen, Y.; Wang, X.; Liu, M.; Li, H.; et al. Nematodes and Microorganisms Interactively Stimulate Soil Organic Carbon Turnover in the Macroaggregates. Front. Microbiol. 2018, 9, 2803. [CrossRef]

89. Smith, A.P.; Marín-Spiotta, E.; de Graaff, M.A.; Balser, T.C. Microbial community structure varies across soil organic matter aggregate pools during tropical land cover change. Soil Biol. Biochem. 2014, 77, 292-303. [CrossRef]

90. Bongiorno, G.; Bodenhausen, N.; Bünemann, E.K.; Brussaard, L.; Geisen, S.; Mäder, P.; Quist, C.W.; Walser, J.; Goede, R.G.M. Reduced tillage, but not organic matter input, increased nematode diversity and food web stability in European long-term field experiments. Mol. Ecol. 2019, 28, 4987-5005. [CrossRef] [PubMed]

Publisher's Note: MDPI stays neutral with regard to jurisdictional claims in published maps and institutional affiliations.

(C) 2020 by the authors. Licensee MDPI, Basel, Switzerland. This article is an open access article distributed under the terms and conditions of the Creative Commons Attribution (CC BY) license (http://creativecommons.org/licenses/by/4.0/). 